\title{
A Study on the Practical Grounding System in Power Distribution Lines
}

\author{
Teru Miyazaki Member (Tokyo Electric Power Company, miyazaki.teru@tepco.co.jp) \\ Shigemitsu Okabe Senior Member (Tokyo Electric Power Company, okabe.s@tepco.co.jp) \\ Kiyoshi Aiba Member (Tokyo Electric Power Company, aiba.kiyoshi@tepco.co.jp) \\ Takao Hirai Member (Tokyo Electric Power Company, hirai.t@tepco.co.jp) \\ Jun Yoshinaga Member (Tokyo Electric Power Company, yoshinaga.jun@tepco.co.jp)
}

Keywords: lightning, distribution line, surge, arrester, direct stroke, indirect stroke

It is important for electric power companies to maintain grounding resistances adequately for the safety of the public. But they have difficulty in managing those grounding systems because vast amounts of grounding electrodes are installed in distribution lines. Based on the statistical data of surge currents through lightning arrestors and electrical surges in customers, a rated value of the grounding resistance for lightning arrestors on distribution lines was specified in the 1960's. A grounding system is shown in Fig. 1. But equipment of distribution lines has changed since the Criteria were established. And as such, they cannot cover all of actual grounding systems in fields. Quantitative evaluation that is based on analysis these days is critical to optimizing grounding designs.

TEPCO had conducted field research to measure the waveforms of surge voltage and current in order to rationalize the lightning protection design of distribution lines. And the authors proposed a lightning-surges analysis model based on the observation data.

In this study, a lightning surge analysis for the rationalization of the grounding system was carried out by means of the EMTP. The calculation conditions were set based on the observation data. The distributions of surge current and voltage into costumers site due to direct lightning strokes were calculated with the Monte Carlo method.

As a result, the practical grounding systems were proposed on condition that risks of damages of electric appliances from lightning do not increase (See Fig. 2). That can be useful for the Electric Power Companies to manage grounding systems.

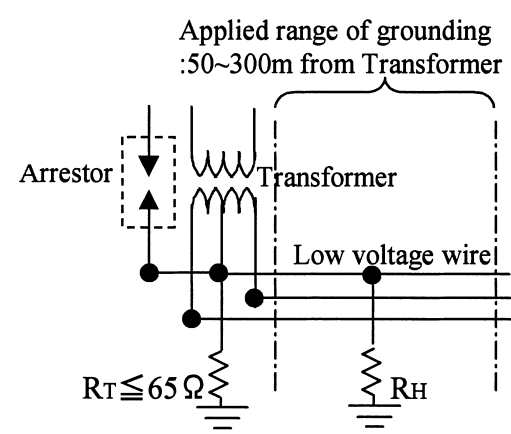

Parallel resistance of $\mathrm{RT}, \mathrm{RH} \leqq 20 \Omega$

Fig. 1. Examples of the grounding system in the criteria

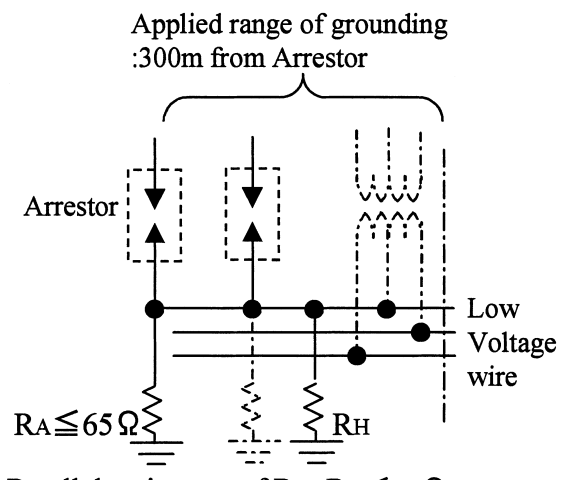

Parallel resistance of $\mathrm{RA}, \mathrm{RH} \leqq 16 \Omega$

Fig. 2. Example of practical grounding system 


\title{
設備実態を考慮した配電線接地設計の検討
}

$\begin{array}{llllll}\text { 正 員 宮崎 } & \text { 輝* } & \text { 上級会員 岡部 } & \text { 成光* } \\ \text { 正 員 饗場 } & \text { 潔* } & \text { 正 員 平井 崇夫* } \\ \text { 正 員 吉永 } & \text { 淳* } & & & \end{array}$

\begin{abstract}
A Study on the Practical Grounding System in Power Distribution Lines
Teru Miyazaki*, Member, Shigemitsu Okabe*, Senior Member, Kiyoshi Aiba*, Member, Takao Hirai*, Member, Jun Yoshinaga*, Member
\end{abstract}

It is important for electric power companies to maintain grounding resistances adequately for the safety of the public. But they have difficulty in managing those grounding systems because vast amounts of grounding electrodes are installed in distribution lines. Based on the statistical data of surge currents through lightning arrestors and electrical surges in customers, a rated value of the grounding resistance for lightning arrestors on distribution lines was specified in the 1960's.

TEPCO had conducted field research to measure the waveforms of surge voltage and current in order to rationalize the lightning protection design of distribution lines. And the authors proposed a lightning-surges analysis model based on the observation data. In this study, a lightning surge analysis for the rationalization of the grounding system was carried out by means of the EMTP. The calculated results suggest that a practical grounding design is possible. That can be useful for the Electric Power Companies to manage grounding systems.

キーワード: 雷, 配電線, サージ, 避雷器, 直撃雷, 誘導雷

Keywords: lightning, distribution line, surge, arrester, direct stroke, indirect stroke

\section{1. まえがき}

配電用の接地は保安用として用いられるものが多く，接 地抵抗の的確な管理が求められている。特に避雷器の接地 は, 電気設備技術基準・解釈 ${ }^{(1)}$ (以下, 電技解釈と略す) に より，接地抵抗の規定值が法的に規制されている。一方， 大地は土壤毎に，また深さによっても特性が異なり，大地 抵抗率が高い土壤において接地抵抗規定值を得るためには, 多大な労力と費用が必要となる。更に, 配電系統の接地は, 膨大な数の設備数から, 電力会社ではそれらの維持. 管理 に苦慮している現状にある。

避雷器の接地設計は, 過酷な誘導雷サージによる避雷器 放電電流が接地極に流入し，低圧配電線電位が上昇した場 合に需要家機器の耐量との協調が保たれる観点から定めら れている (2)。しかし，近年の耐雷素子内蔵型柱上変圧器等 の普及など，実フィールドの設備形態が変化しており，現 行電技解釈の接地設計では対応しきれない場合もある。

\footnotetext{
*東京電力 (株) 技術開発研究所 高電圧・絶縁技術グループ

干 230-8510 横浜市鶴見区江ヶ崎町 4-1

High voltage \& Insulation Group. R\&D Center, TEPCO

4-1, Egasaki-cho, Turumi-ku, Yokohama 230-8510
}

東京電力では，実配電線における雷撃様相の総合観測を 実施し, 雷撃時に配電線に生じる雷サージの伝搬様相の実 態がより明らかになりつつある。また, 配電系統から需要 家まで一貫した EMTP 解析モデルを構築し, 観測で得られ た雷サージ電流, 電圧波形, およびそれらの波高值の統計 分布を概ね再現することを確認し(3)(4)，より実現象に即した 検討が可能となってきた。

本論文では, 避雷器接地に関わる法令について整理を行 い, 近年の観測データ, 解析手法に基づき, 設備実態を考 慮した接地合理化の検討を行った結果を示す。

\section{2. 現行電技解釈の整理と課題}

現行電技解釈 42 条に記載されている避雷器接地設計に

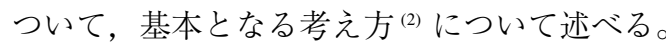

$\langle 2 \cdot 1\rangle$ 単独接地 図 1 に電技解釈 42 条第一号で規定 されている単独接地の形態を示す。同困において, 避雷器 と柱上変圧器の接地極は, それぞれ単独に施設される。調 査結果に基づく避雷器放電電流過酷值（1 kA）が発生した 場合に, 変圧器の耐電圧および需要家家電機器の耐電圧を 超過しないことを条件に, 避雷器接地抵抗規定值 $30 \Omega$ が定 められた。 


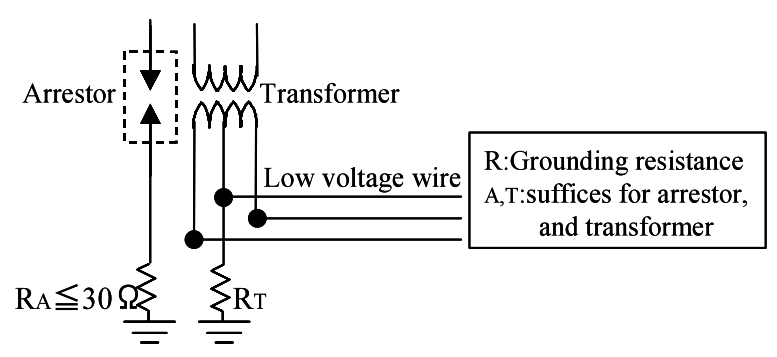

図 1 単独接地の例（解釈 42 条第一号）

Fig. 1. Example of standard grounding system.

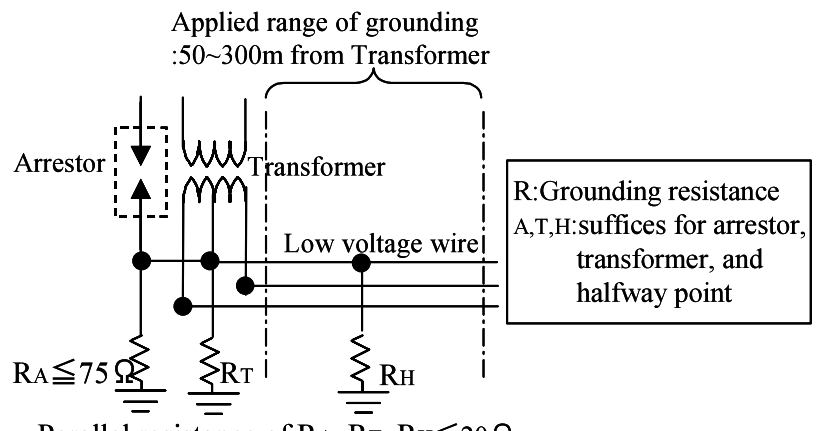

Parallel resistance of $\mathrm{RA}, \overline{\mathrm{RT}}, \mathrm{RH} \leqq 20 \Omega$

(a) In case of low voltage wire

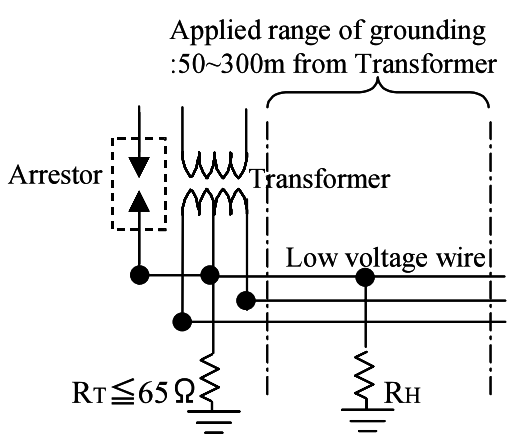

Parallel resistance of $\mathrm{RT}, \mathrm{RH} \leqq 20 \Omega$

(b) In case of low voltage wire (common earthing)

図 2 連接接地の例（解釈 42 条第二号）

Fig. 2. Examples of coupling grounding system.

$\langle\mathbf{2} \cdot \mathbf{2}\rangle$ 連接接地連接接地の場合, 柱上変圧器に印 加される電圧は，避雷器の制限電圧以下に抑制される。し かし, 避雷器放電時の大地電位上昇が直接低圧配電線の侵 入サージとなるため, 中間接地を施設することによりサー ジを抑制する。

図 2 に電技解釈第 42 条第二号に規定されている連接接 地の例を示す。同図 (a)の場合，低圧配電線に発生する電 位が，単独接地による場合と同等であることを条件として， 接地抵抗規定值（避雷器接地抵抗 $75 \Omega$, 合成抵抗 $20 \Omega$ ）が 定められた。同図 (b) は, 変圧器柱で避雷器と変圧器接地 を共用する場合を示す。

図 3 に電技解釈 42 条第三号で規定されている接地形態 を示す。この形態において, 避雷器と柱上変圧器が各々別 柱に施設され，接地線は低圧架空電線に接続し，避雷器柱 単極 $65 \Omega$ ，および合成抵抗值 $16 \Omega$ が定められている。

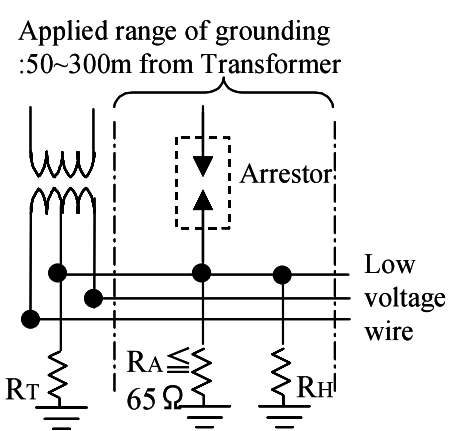

Parallel resistance of $\mathrm{RA}, \overline{\mathrm{RT}}, \mathrm{RH} \leqq 16 \Omega$

図 3 連接接地の例 (解釈 42 条第三号)

Fig. 3. Example of coupling grounding system.

本論文では，電技解釈 42 条第二号（図 2(b)）を対象に， より設備実態を考慮した接地設計を提案することを目的と した検討を実施した。

\section{3. 解析による避雷器接地設計の検討}

〈3・1〉 検討項目 現行電技解釈の保安レベルを維持 することを条件に, 接地設計の検討を行う。過去の検討で 基準となった低圧配電線接地相の対地電圧，および需要家 引込線電流を本検討における評価基準とする。過去の検討 で，引込線電流は対象外であったが，本検討では評価の対 象とした。検討項目を以下に記す。

（1）現行電技解釈に基づく合理化 現行電技解釈 42 条第二号 (図 2(b)) において, 変圧器柱から半径 $50 \mathrm{~m}$ 以 内は合成抵抗適用範囲として認められておらず，分かりに くさに原因の一つとなっている。本項では, 変圧器柱から $50 \mathrm{~m}$ 以内を合成抵抗適用範囲として適用可能かどうか検討 する。中間接地の位置をパラメータとして，現行電技解釈 42 条第二号（図 2(b)）に適合する場合, 不適合の場合の解 析モデルを設定する。

・電技解釈に適合する形態：

中間接地が変圧器柱から $50 \mathrm{~m}$ 以上 $300 \mathrm{~m}$ 以内に施設 される場合。

- 電技解釈に不適合の形態：

中間接地が変圧器柱から $50 \mathrm{~m}$ 未満に施設される場合 両ケースにおいて，需要家侵入サージを比較し，電技解 釈適合形態，不適合形態で有意差が発生するか検討する。 仮に有意差が発生しないならば，両者を統合した図 4 の接 地形態にしても，現行電技解釈と同等の保安レベルを維持 可能と考えられる。

（2）設備実態を考慮した合理化現行電技解䣋 (図 2(b)）は変圧器を中心に接地形態が定まっているが, 実設備では避雷器が単独で施設される場合が多数ある。更 には, 合成抵抗適用範囲である変圧器柱から半径 $300 \mathrm{~m}$ 以 内に, 別の避雷器が施設される形態もあり, 電技解釈に設 備実態が適合しない場合がある。そこで，検討 $(1)$ で定ま る合理化後の形態（図 4) において需要家侵入サージを算定 し，需要家侵入サージが同等以下であることを条件に，設 


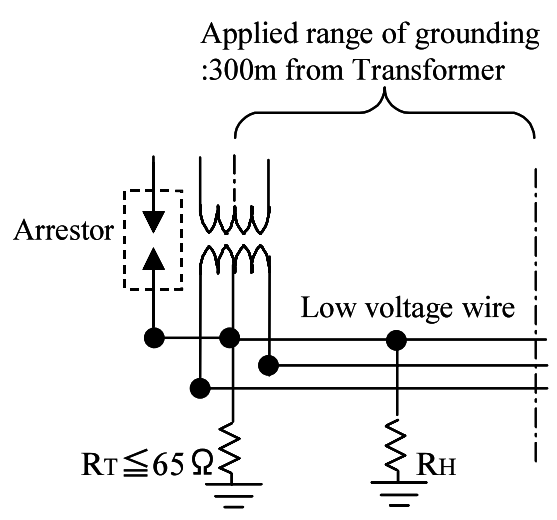

Parallel resistance of $\mathrm{RT}, \mathrm{RH}_{\mathrm{H}} \leqq 20 \Omega$

困 4 合理化後の接地形態

Fig. 4. Grounding system based on the rationalization.

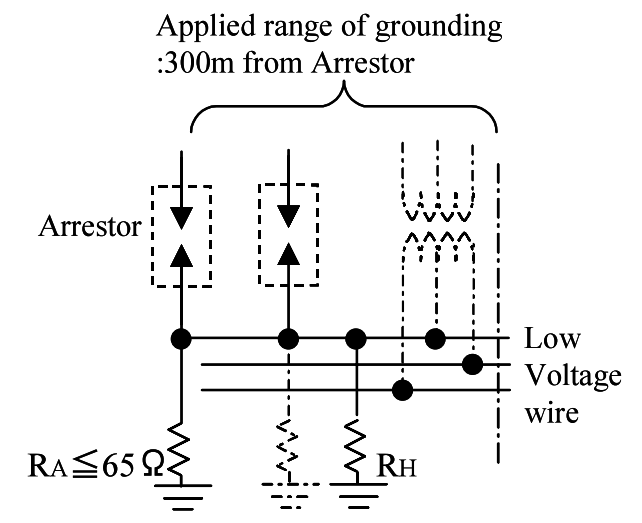

Parallel resistance of $\mathrm{RA}, \mathrm{RH} \leqq ? \Omega$

図 5 設備実態を考慮した接地形態

Fig. 5. Example of practical grounding system.

備実態を考慮した避雷器を中心とした形態（図 5）に打け る合成抵抗值を求める。

(3) 単極抵抗值 · 合成抵抗值の合理化 現行電技解 釈において単極抵抗值が規定值の $65 \Omega$ を超過する場合は, 当該柱で規定值を得るまで改修を行う必要があり，土壤に よっては多大な費用を要する場合がある。そこで，単極抵 抗值と合成抵抗值の組み合わせのバリエーションを増やし， より自由度の高い接地形態を得ることを目的とした検討を 行う。検討 (2)で定まる設備実態を考慮した形態（図 5)に おいて，需要家侵入サージを増加させないことを条件に， 避雷器柱単極抵抗值と合成抵抗值の可能な組み合わせを求 める。

〈3・2〉検討雷撃種別の選定配電線雷観測デー夕に 基づき，検討対象とする雷撃種別（直撃雷・誘導雷）を選定 する。図 6 に東京電力受持ち区域内における雷観測デー夕 の耐雷素子放電電流の分布 ${ }^{(5)}$ と避雷器接地抵抗值の根拠と なった過去（昭和 30 年代）の避雷器放電電流の統計分布 ${ }^{(2)}$ との比較を示す。図中の「全デー夕」には, 雷撃種別（直 撃雷・誘導雷) 不明のデータも含まれる。過去に誘導雷と されている分布は，東京電力の観測結果の直撃雷・誘導雷 混在の分布に類似する。また，現行電技解釈の根拠となっ

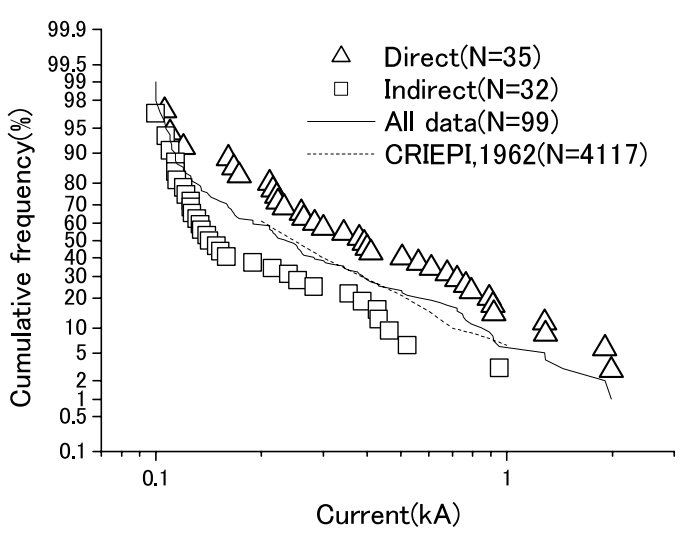

図 6 耐雷素子放電電流の累積発生頻度

Fig. 6. Cumulative frequency of crest value of surge current through $\mathrm{ZnO}$ elements.

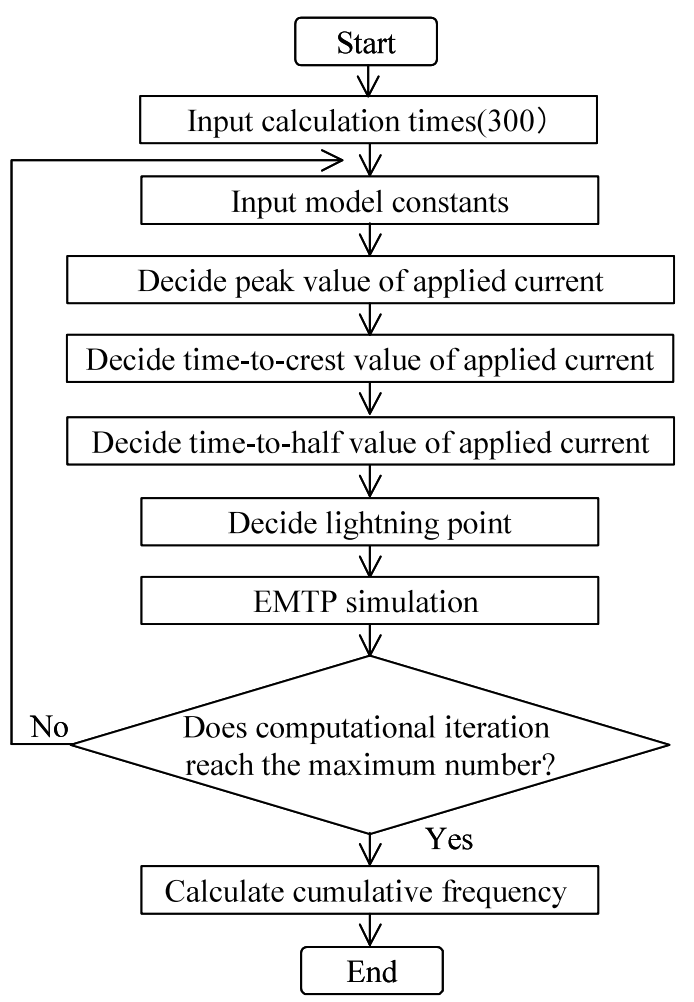

図 7 直撃雷解析プログラムのアルゴリズム

Fig. 7. Algorithm of direct lightning analysis program.

た過酷な放電電流 5\%值（1 kA）は，殆どの場合直撃雷に より発生していることから, 解析上の模擬として直撃雷を 検討対象とする。

$\langle\mathbf{3} \cdot \mathbf{3}\rangle$ 需要家侵入サージ評価手法 直撃雷発生時の 需要家侵入サージ分布を算定することを目的として, 需要 家侵入サージ評価プログラムを構築した。図 7 にプログラ ムのアルゴリズムを示す。プログラムの概要は, 雷電流波 形を決定し, 系統全ての電柱に打ける需要家侵入サージ（需 要家引込線電流・低圧配電線電圧）の計算を EMTP 解析プ ログラムにより実行する。1つの計算が終了すると雷撃柱 を別の柱に移して, 次の印加電流波形に基づき同様の解析 
表 1 解析条件

Table 1. Conditions for analysis.

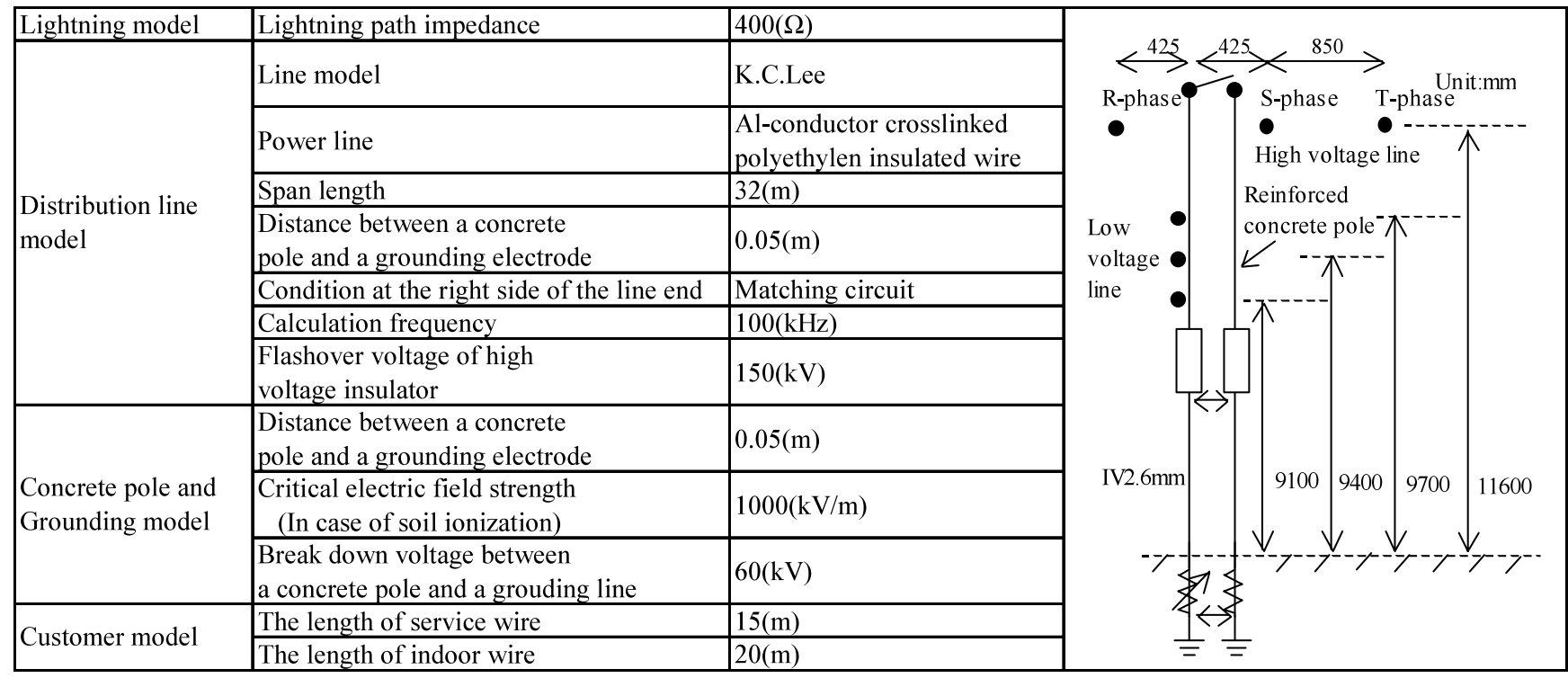

を実施する。この解析は需要家侵入サージ波高值の平均值 が収束するまで継続して実施することを想定し，300回の 繰り返し計算を行う。計算終了後，需要家侵入サージ波形 波高值の発生頻度分布および平均值を算定する。

〈3.4〉 解析モデル 東京電力の設備デー夕を基に解 析用モデルを構築した。表 1 に解析条件を示す。

（1）柱体・接地文献(6) を基にモデルを構築した。 地中部分は柱体・接地極間の相互抵抗を考慮し，接地極に関 しては土中放電による接地抵抗值低減特性を模擬した。モ デルの定数は大地抵抗率, 柱体と接地極の径と配置によって 決まる。柱体地中部の抵抗值は, 接地棒電極抵抗值と接地抵 抗計算式より算定される大地抵抗率より想定した。ただし， 非接地柱に関しては土壤の大地抵抗率を想定することがで きないので，文献 (7) を基に，過酷な大地抵抗率 $1000[\Omega \mathrm{m}]$ を適用して柱体地中部の抵抗値を算出した。

地上部分は柱体・接地線を相互分も含めた分布定数線路 として取扱い，接地線一柱体鉄筋間のスパークオーバ (以下, 柱体 S.O. と略す) 模擬として，接地線上部に放電ギャップ スイッチを設定した。柱体 S.O. 電圧設定值は観測データと 最も整合が得られた $60 \mathrm{kV}$ に設定した ${ }^{(4)}$ 。

(2) 配電系統配電線は 6 相分布定数回路で模擬し た。架空地線 $(\mathrm{GW})$ の無い線路を想定しているのは, 現 行電技解釈 42 条は $\mathrm{GW}$ 無しの線路で規定されているため である。柱上トランスは文献 (8) に記載されているモデル を適用し，避雷器は非線形の抵抗特性により表現した。高 圧クランプ碍子のフラッシオーバはスイッチで模擬し，動 作閾值を 50\%閃絡值として実態調査に基づき $150 \mathrm{kV}$ に設 定した。

（3）需要家 一般家屋内の家電機器については, 引 込線に侵入するサージに対する評価を目的として，代表的な サージの保護回路（線間：バリス夕，対地間：ギャップ）で

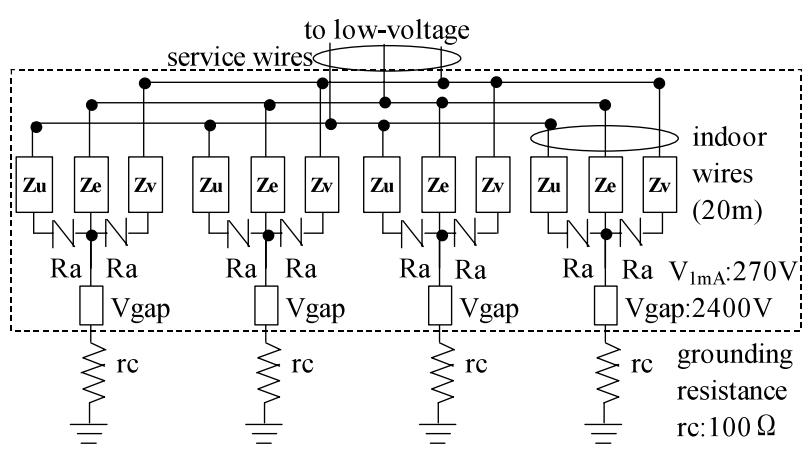

図 8 需要家屋内の EMTP 解析モデル

Fig. 8. EMTP models of customer's facility.

模擬を行った ${ }^{(9)}$ 。図 8 に検討で用いた需要家の回路を示す。 機器の接地抵抗值は文献(10)の実態調査結果を基に $100 \Omega$ を設定した。機器の並列接地極数についても文献 (10) を基 に設定した。

（4）雷撃電流波形雷撃電流波高值は，「発変電所お よび地中線の耐雷設計ガイド」(11) で推奨されている雷撃電 流頻度分布，雷電流波頭長と波尾長に関しては，池田氏ら が国内で観測した統計分布 ${ }^{(12)}$ を適用し，モンテカルロ法 ${ }^{(13)}$ により波形を決定した。雷電流波高值, 波頭長間には, あ る程度相関関係があることが知られている。本検討では, 文献 (14)の手法に従い, モンテカルロ計算実施時は同一の 発生頻度值から波高值, 波頭長, 波尾長を決定することに より，各パラメータ間の相関について考慮する手法を適用 した。

（５）雷撃電流印加箇所 雷撃電流の印加箇所は東京 電力の配電線雷観測データを基に設定した ${ }^{(3)}$ 。配電設備へ の直撃雷観測事例 33 例について, 電柱頂部への雷撃が最 も多く全 33 事例中約 6 割であり, 電柱頂部と $\mathrm{GW}$ 径間へ 


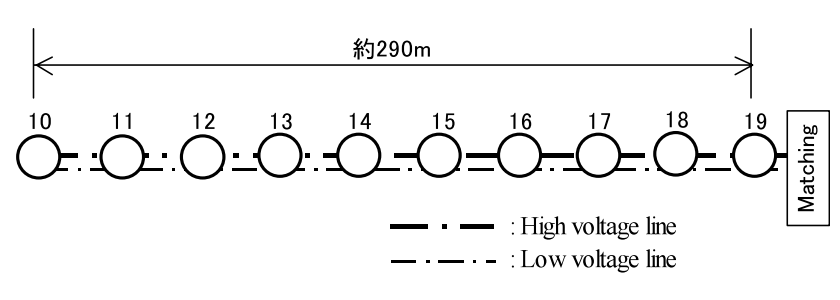

図 9 解析モデル系統

Fig. 9. Configuration of analytical distribution lines.

$$
\text { 表 } 2 \text { 系統デー夕 }
$$

Table 2. Distribution line data.

\begin{tabular}{|c|c|c|c|c|c|c|c|c|c|}
\hline Case No. & A-1 & A-2 & A-3 & A-4 & A-5 & A-6 & A-7 & A-8 & A-9 \\
\hline \hline $\begin{array}{c}\text { Pole No. with } \\
\text { arrester }\end{array}$ & 10 & 10 & 10 & 10 & 10 & 10 & 10 & 10 & 10 \\
\hline $\begin{array}{c}\text { Pole No. with } \\
\text { transformer }\end{array}$ & 10 & 10 & 10 & 10 & 10 & 10 & 10 & 10 & 10 \\
\hline $\begin{array}{c}\text { Pole No. with } \\
\text { grounding }\end{array}$ & 10,11 & 10,12 & 10,13 & 10,14 & 10,15 & 10,16 & 10,17 & 10,18 & 10,19 \\
\hline $\begin{array}{c}\text { conformed } \\
\text { to the Criteria }\end{array}$ & $\times$ & \multicolumn{10}{|c}{ O } \\
\hline & O Conformed to the Criteria \\
& : Not conformed to the Criteria
\end{tabular}

(b) Case B

\begin{tabular}{|c|c|c|}
\hline Case No. & B-1 & B-9 \\
\hline \hline $\begin{array}{c}\text { Pole No. with } \\
\text { arrester }\end{array}$ & 10 & 10 \\
\hline $\begin{array}{c}\text { Pole No. with } \\
\text { transformer }\end{array}$ & 10 & 10 \\
\hline $\begin{array}{c}\text { Pole No. with } \\
\text { grounding }\end{array}$ & 10,11 & 10,19 \\
\hline
\end{tabular}

(c) Case $\mathrm{C}$

\begin{tabular}{|c|c|c|c|c|c|c|c|c|}
\hline Case No. & C-111 & C-119 & C-911 & C-919 & C-191 & C-199 & C-991 & C-999 \\
\hline $\begin{array}{c}\text { Pole No. with } \\
\text { arrester }\end{array}$ & 10,11 & 10,19 & 10,11 & 10,19 & 10,11 & 10,19 & 10,11 & 10,19 \\
\hline $\begin{array}{c}\text { Pole No. with } \\
\text { transformer }\end{array}$ & 11 & 11 & 11 & 11 & 19 & 19 & 19 & 19 \\
\hline $\begin{array}{c}\text { Pole No. with } \\
\text { grounding }\end{array}$ & 10,11 & 10,11 & 10,19 & 10,19 & 10,11 & 10,11 & 10,19 & 10,19 \\
\hline
\end{tabular}

の雷撃を併せると全事例中約 9 割となった。また $\mathrm{GW} の$ 無 い線路に打いても 8 割以上が柱頂に落雷した。以上の結果 より，柱頂に落雷位置を設定した。

$\langle\mathbf{3} \cdot \mathbf{5}\rangle$ 解析用線路構成 低圧架空電線について, 中 間接地柱の位置をパラメータにした解析用線路を設定する。 図 9 と表 1 は解析用線路構成を示し, 表 2(a), (b), (c) に, 図 2(b) に相当するCase A, 図 4 に相当するCase B，抢よび 図 5 に相当する Case C の解析モデルを各々設定した。図 9 で 10 号柱の左側を整合していないのは, 需要家侵入サージ が過酷となる配電系統の末端を想定したためである。例え ば, Case A-1 は電技解釈不適合形態, Case A-2 Case A-9 は電技解釈適合形態となる。な掠，系統全ての柱において， 電柱 1 基当たり需要家モデルが 1 軒ずつ接続される。

〈3.6〉検討パラメータ 先に述べた検討項目に対し て,パラメータを以下のように定める。

（1）現行電技解釈に基づく合理化 表 3(a) に検討パ ラメータを示す。Case A の電技解釈適合ケース，不適合
表 3 検討パラメータ

Table 3. Investigated parameters.

(a) Rationalization of grounding system

\begin{tabular}{|l|c|c|}
\hline \multicolumn{1}{|c|}{ Parameters } & Case A & Case A-2 Case A-9 \\
\hline \hline Peak value $(\mathrm{kA})$ & Monte & Monte \\
\cline { 1 - 1 } Time-to-crest value $(\mu \mathrm{sec})$ & Carlo & Carlo \\
Time-to-half value $(\mu \mathrm{sec})$ & method & method \\
\hline Parallel grounding resistance $(\Omega)$ & 20 & 20 \\
\hline
\end{tabular}

(b) Practical grounding system

\begin{tabular}{|l|c|c|}
\hline \multicolumn{1}{|c|}{ Parameters } & Case B & Case C \\
\cline { 1 - 1 } Peak value $(\mathrm{kA})$ & Monte & Monte \\
Time-to-crest value $(\mu \mathrm{sec})$ & Carlo & Carlo \\
method & method \\
\hline Time-to-half value $(\mu \mathrm{sec})$ & 20 & 20,16 \\
\hline
\end{tabular}

(c) Advanced grounding system

\begin{tabular}{|c|c|c|}
\hline Parameters & \multicolumn{2}{|c|}{ Case C-119 } \\
\hline Peak value (kA) & \multirow{3}{*}{$\begin{array}{l}\text { Monte } \\
\text { Carlo } \\
\text { method }\end{array}$} & \multirow{3}{*}{$\begin{array}{l}\text { Monte } \\
\text { Carlo } \\
\text { method }\end{array}$} \\
\hline Time-to-crest value ( $\mu \mathrm{sec})$ & & \\
\hline Time-to-half value ( $\mu \mathrm{sec}$ ) & & \\
\hline $\begin{array}{l}\text { Grounding resistance } \\
\text { for arrestor }(\Omega)\end{array}$ & 65 & $\begin{array}{c}30,100 \\
200,300\end{array}$ \\
\hline $\begin{array}{l}\text { Parallel grounding } \\
\text { resistance }(\Omega)\end{array}$ & 16 & $\begin{array}{c}12,14,16, \\
18,20\end{array}$ \\
\hline
\end{tabular}

ケース各々に扔いて需要家侵入サージを算出し, 相対比較 を実施する。

（2）設備実態を考慮した合理化 表 3(b)に検討パラ メータを示す。Case B, Case C 各々において需要家侵入 サージを算出し，相対比較を実施する。

(3) 単極抵抗值 ·合成抵抗值の合理化表 3(c) に検 討パラメータを示す。Case C-119 の解析モデル系統にお いて, 避雷器柱単極抵抗值と合成抵抗值の組み合わせを求 める。

\section{4. 解析結果と評価}

本検討では，接地設計を変更した場合に，系統内に接続 される需要家に発生する雷リスクを同等以下に抑制する考 え方に基づき, 評価項目を需要家 1 軒当たりに発生する侵 入サージ（電流・電圧）の平均值，䇽よび侵入サージ分布 とした。最終的な評価の際に, 分布も評価項目としたのは, 平均值のみを評価項目とした場合, 分布の形状が異なって いても同一の平均值が算出される可能性があるからである。 平均值だけでなく分布としても同様であれば，系統に接続 される需要家全体の雷リスクは同等であると考えられる。

$\langle 4 \cdot 1\rangle$ 現行電技解釈に基づく合理化 図 10(a), (b)に, 需要家侵入サージの電流, 電圧のケース別平均值を各々示 す。同図に扔いて, 解析結果は代表的なケースのみを示し, 横棒は現行電技解釈に適合するケース (Case A-2, Case A9）の需要家侵入サージレベルを表す。電技解釈不適合形 態（Case A-1）に扔ける侵入サージは，電技解釈適合形態 (Case A-2, Case A-9) における值とほぼ同一であり, 平均值 収束後の変動範囲内 (電流: 数 $10 \mathrm{~A}$ 程度, 電圧: 数 $100 \mathrm{~V}$ 程 度)に収まる結果となった。一般的な家電機器の大地間には 


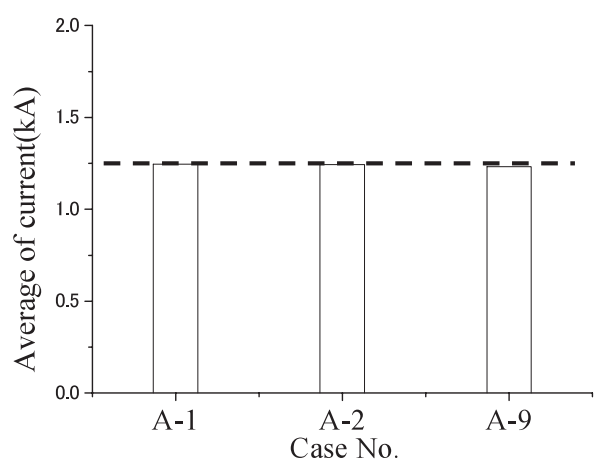

(a) Average of current into service wire

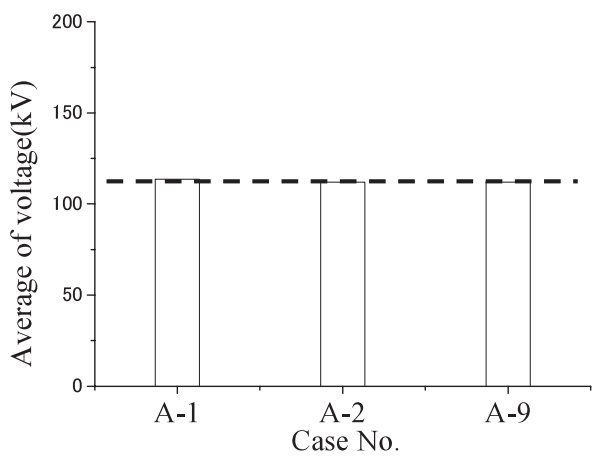

(b) Average of voltage at low-voltage line

図 10 需要家侵入サージ平均值 (Case A)

Fig. 10. Average of surge level at customer (Case A).

動作開始電圧 $1800 \mathrm{~V} \sim 2400 \mathrm{~V}$, サージ耐量 $1000 \mathrm{~A} \sim 2500 \mathrm{~A}$ の避雷素子が挿入されている(9) ことを考慮しても，各々の ケース間の雷リスクは同等であると考えられる。図 11(a), (b) は, 需要家侵入サージ電流累積発生頻度分布, 拈よび電 圧分布をそれぞれ示し，分布としても電技解粕適合形態と 電技解釈不適合形態に扔いてほぼ同等であった。よって， 両者の安全レベルは同等であると推定される。以上の結果 より, 中間接地の位置が需要家の雷リスクに与える影響は 少ないと想定され，図 4 のように合成抵抗適用範囲を統合 した接地形態が可能と考えられる。

$\langle\mathbf{4} \cdot \mathbf{2}\rangle$ 設備実態を考慮した合理化 図 12(a), (b) に, 需要家侵入サージの電流, 電圧のケース別平均值を各々示 す。現行電技解釈に基づく合理化後の形態（図 4 : Case B) に抢いて発生する需要家侵入サージ (同図の横棒) を増加 させないことを条件に，設備実態を考慮した形態（図 5： Case C) に扔ける合成抵抗值を求める。

(1) Case C の合成抵抗值: $20 \Omega$ Case B（合成抵抗 $20 \Omega$ ) と Case C (合成抵抗 $20 \Omega$ ) で電圧平均值に扔いて有 意な差は発生しなかった（図 12(b)）。しかし, 電流平均値 (図 12(a)）において, Case C の方がCase B よりも $30 \mathrm{~A}$ 程 （最大波高值の約 $2 \% ）$ 高いケースが確認され，平均值収束 後の変動幅（約 $20 \mathrm{~A} ）$ 以上の差異となった。

(2) Case $\mathrm{C}$ の合成抵抗值：16 $\Omega$ Case $\mathrm{C}$ (合成抵抗 $16 \Omega)$ における需要家侵入サージは, 電流平均値, 電圧平 均值とも, Case B（合成抵抗 $20 \Omega$ ）に打ける侵入サージ 以下の值となった（図 12）。Case C のどのケースにおいて

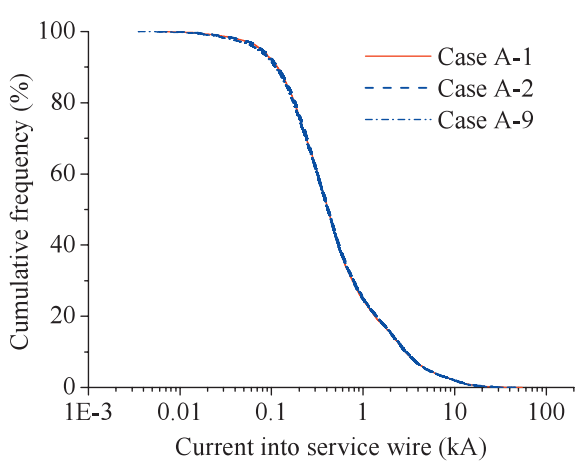

(a) Distribution of current into service wire

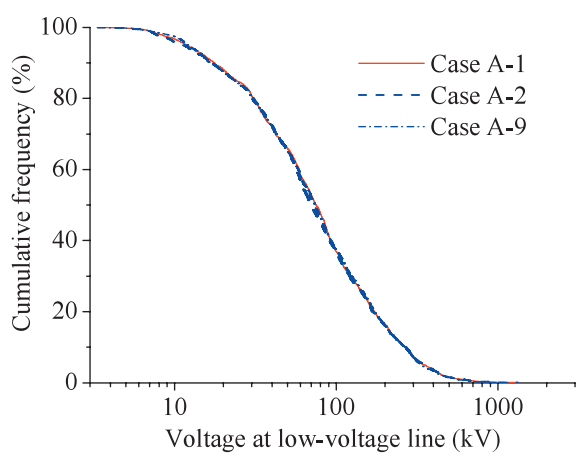

(b) Distribution of voltage at low-voltage line

困 11 需要家侵入サージ分布 (Case A)

Fig. 11. Distribution of surge level at customer (Case A).

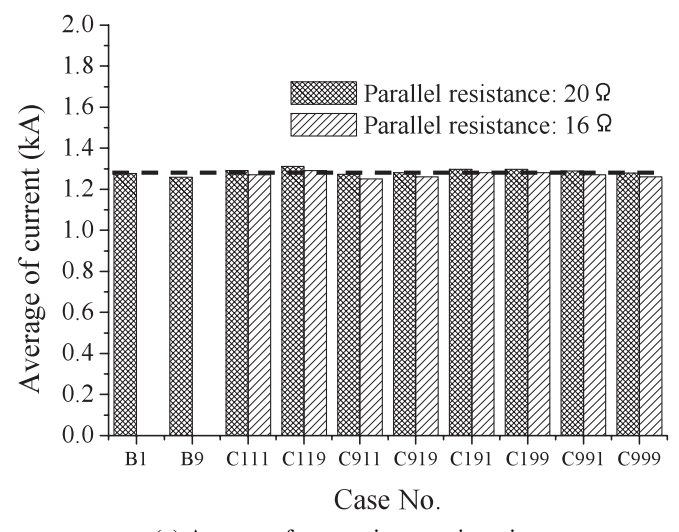

(a) Average of current into service wire

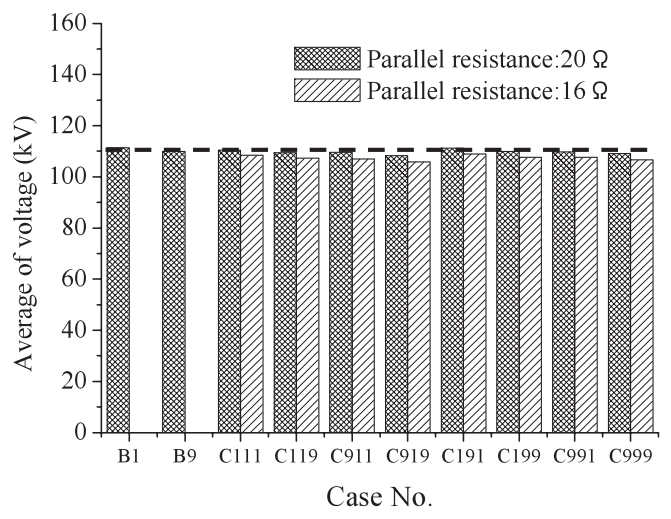

(b) Average of voltage at low-voltage line

困 12 需要家侵入サージ平均值 (Case B, C)

Fig. 12. Average of surge level at customer (Case B, C). 


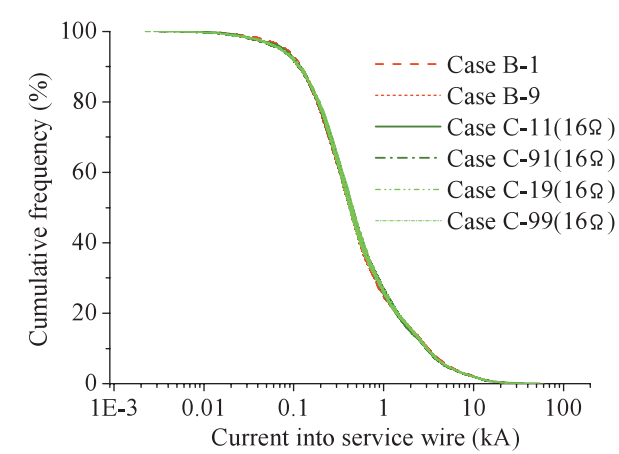

(a) Distribution of current into service wire

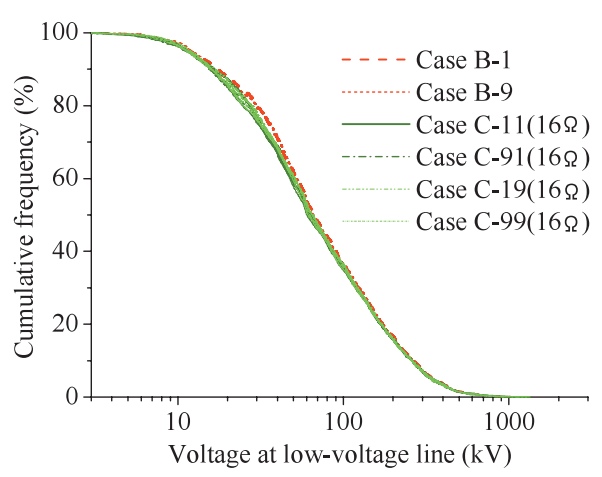

(b) Distribution of voltage at low-voltage line

図 13 需要家侵入サージ分布 (Case B, C)

Fig. 13. Distribution of surge level at customer (Case B, C).

も，合成抵抗值が $20 \Omega$ から $16 \Omega$ にしたことで，需要家侵 入サージが低減した。図 13 にケース別の需要家侵入サー ジの累積発生頻度分布を示す。頻度分布としても, Case C （合成抵抗 $16 \Omega$ ）に抒ける分布は, Case B（合成抵抗 $20 \Omega$ ) における分布以下であることを確認した。

以上の (1)，(2)より，設備実態を考慮した形態におい て，合成抵抗值を $16 \Omega$ 以下にすれば，需要家に発生する サージは, 現行電技解釈に基づく合理化後の形態におけるも のよりも同等以下に抑制されると想定される。また，設備 実態を考慮した形態は, 電技解釈 42 条第三号の形態 (図 3) に近く，その規定值である合成抵抗值 $16 \Omega$ を設定すると第 三号との整合がとれる。よって，設備実態を考慮した形態 において，合成抵抗值を $16 \Omega$ に設定した図 14 の接地形態 であれば，需要家に与える雷リスクは同等以下に抑制され ると評価する。なお，同図に扮いて避雷器が 2 箇所以上増 えた場合についても解析を行い, 需要家侵入サージは現行 電技解釈に基づく合理化後の形態におけるものよりも同等 以下に抑制されることを確認している。系統内に避雷器が 複数追加される場合においても，提案する接地形態は可能 であると考えられる。

$\langle\mathbf{4} \cdot \mathbf{3}\rangle$ 単極抵抗值・合成抵抗值の合理化これまで の検討で, 中間接地の位置が需要家侵入サージ分布に与え る影響は少ないことを確認したので，設備実態を考慮した 形態（図 14）に相当する解析モデルとして，Case C-119を 代表ケースとして選定した。Case C-119において，避雷器 柱単極抵抗值： $65 \Omega$, 合成抵抗值： $16 \Omega$ に設定した場合に

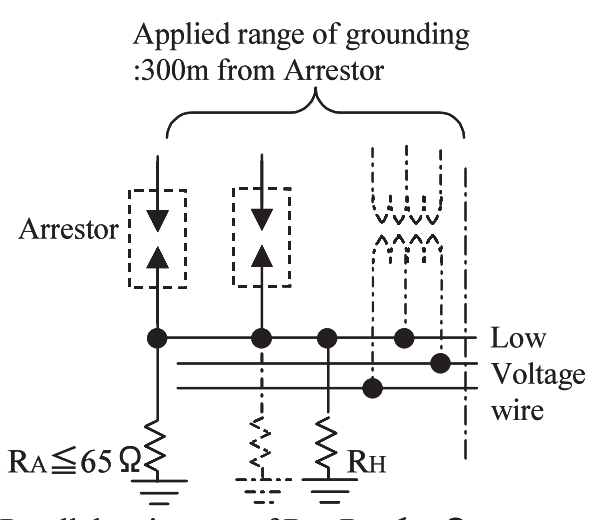

Parallel resistance of $\mathrm{RA}, \mathrm{RH} \leqq 16 \Omega$

図 14 設備実態を考慮した接地形態

Fig. 14. Example of practical grounding system.

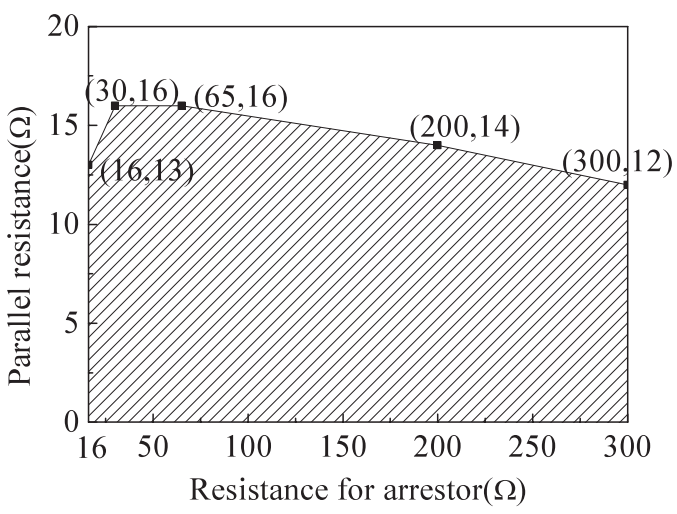

図 15 電技解釈に適合する抵抗值の組み合わせ

Fig. 15. Combination of resistances conformed to the Criteria.

発生する需要家侵入サージを増加させないことを条件に求 めた単極抵抗值と合成抵抗值の組み合わせを図 15 に示す。 これらの組み合わせにおいて, 現行電技解釈と同等の安全 レベルを確保可能と考えられる。同図において, 単極抵抗 值が $16 \Omega$ ，または $300 \Omega$ に近づくほど，合成抵抗值を抑制 する必要がある。これらの場合, 単極抵抗值が $16 \Omega$ では 中間接地抵抗值は $68 \Omega$, また, 単極抵抗值が $300 \Omega$ では中 間接地抵抗值は $13 \Omega$ にする必要があり，両ケースにおい て単極接地抵抗值と中間接地抵抗值が不均衡になる。この ような場合は，系統内の接地極数が 1 極の場合に近くなる ため, 需要家侵入サージが厳しくなり, 合成抵抗值を $16 \Omega$ より小さな值に抑制する結果になったと推察される。

\section{5. まとめ}

電技解釈 42 条第二号を対象として, 需要家侵入電流掞よ び低圧系統に発生する雷過電圧の計算を行い，下記の結果 を得た。

（1）中間接地の位置をパラメー夕に，電技解釈適合形 態，電技解釈不適合形態に該当するモデルを設定した。そ して, 各々のケースに扔ける需要家侵入サージを比較し, 電技解釈適合形態, 不適合形態で有意差が発生するか過電 
圧解析を実施した。その結果，電技解釈適合形態，不適合 形態で各々発生する需要家侵入サージに有意差は見られな かったことより，合成抵抗適用範囲を統合した形態でも現 行電技解釈と同等の安全レベルを確保できると考えられる。

（2）設備実態を考慮した接地形態を提案し，先に述べ た合理化後の形態と同等の保安レベルを維持することが可 能であることを示した。

（3）設備実態を考慮した接地形態において，需要家侵 入サージを増加させないことを条件に, 避雷器柱単極抵抗 值と合成抵抗值の組み合わせを算出した。

本論文では，雷発生時の需要設備側における過電圧等の リスク増加を回避しつつ，最も合理的な維持・管理を可能 とする接地形態について検討を進めた。提案した設備実態 を考慮した接地形態は，現行の配電設備・需要設備が面的 に使用されている限り, 将来的にも十分適用可能な内容で あると考えられる。

(平成 18 年 6 月 28 日受付，平成 18 年 9 月 5 日再受付)

\section{文献}

（1）通商産業省：「電気設備に関する技術基準を定める省令」, 通商産業 省令第 52 号 (1997)

(2) Sectional Committee for Distribution Lines, Lightning Protection Design Study Committee: "Lightning Protection Design Standard for Distribution Lines", J. Technical Laboratory, Vol.13, No.4 (1963) (in Japanese) 耐雷設計基準委員会配電線分科会：「配電線耐雷設計基準要綱」,電 中研技研報, 13, 4 (1963)

(3) T. Hirai, T. Takinami, and S. Okabe: "Observation of Lightning Phenomena on Real Distribution Lines", The Papers of Joint Technical Meeting on Electrical Discharges, Switching and Protecting and High Voltage Engineering, IEE Japan, HV-01-94 (2001)

(4) T. Miyazaki, K. Mori, K. Aiba, T. Hirai, and S. Okabe: "Verification of the EMTP Model for Direct Lightning on Power Distribution Lines", Proc. of the Eleventh Annual Conference of Power \& Energy Society, IEE Japan, No.288 (2005-8) (in Japanese)

宮崎 輝・森健二郎・饗場 潔·平井崇夫·岡部成光：「配電線直撃 雷解析モデルの検証」, 平成 17 年電気学会電力・エネルギー部門大 会, No.288 (2005-8)

(5) T. Miyazaki, S. Okabe, K. Aiba, and T. Hirai: "Statistical Analysis of Lightning Surges on Distribution Lines Based of the Observation", IEEJ Trans. $P E$, Vol.126-B, No.1, pp.97-104 (2006-1) (in Japanese) 宮崎 輝・岡部成光・饗場 潔・平井崇夫：「観測に基づく配電線雷 サージの統計分析」, 電学論 B, 126, 1, pp.97-104 (2006-1)

(6) T. Miyazaki, K. Mori, K. Aiba, T. Hirai, S. Okabe, and S.Sekioka: "Verification of the EMTP Model of Concrete Pole and Grounding Electrode in Distribution Lines", Proc. of the Eleventh Annual Conference of Power \& Energy Society, IEE Japan, No.289 (2005-8) (in Japanese)

宮崎 輝・森健二郎・饗場 潔・平井崇夫・岡部成光・関岡昇三： 「配電線柱体・接地 EMTP モデルの検証」, 平成 17 年電気学会電力. エネルギー部門大会, No.289 (2005-8)

（7） 日本の大地導電率, 電気学会・電子通信学会 (1969)

(8) H. Honda, S. Asakawa, T. Shindo, and S. Yokoyama: "Analysis of the lightning surge propagating through a pole transformer on a real scale distribution line", The Papers of Technical Meeting on High Voltage, IEE Japan, HV-02-56 (2002) (in Japanese)

本田秀樹・浅川 聡・新藤孝敏・横山 茂：「実規模配電線におい て柱上変圧器を介して移行する雷サージの解析」, 電気学会高電圧研 資, HV-02-56 (2002)

(9) Lightning and highly information-oriented society, IEIEJ (1999) (in Japanese)

雷と高度情報化社会, 電気設備学会 (1999)

（10）通商産業省：低圧設備関連 IEC 規格運用技術検討報告書, 電気設備 学会・低圧設備関連 IEC 規格運用技術検討委員会 (2002)

(11) Subcommittee for Power Stations and Substations, Lightning Protection Design Committee: "Guide to Lightning Protection Design for Power

Stations, Substations and Underground Transmission Lines", Technical Report of CRIEPI, No.T40 (1995) (in Japanese)

耐雷設計委員会配電分科会：「発変電所㧍よび地中送電線の耐雷設 計ガイド」, 電中研総合報告, No.T40 (1995)

(12) Ikeda and Sumi: "Lightning current parameters in Japan", Res. Lett. Atmospheric Electricity, Vol.1, pp.41-44 (1987)

(13) A. Asakawa, S. Yokoyama, and Y. Hashimoto: "Development of the Analytical Method for Outage Ratio Due to Lightning on Power Distribution Lines", T. IEE Japan, Vol.114-B, No.10, pp.1050-1058 (1994-10) (in Japanese)

浅川 聡・横山 茂・橋本洋助：「雷による配電線フラッシオーバ 発生率算定手法の開発」, 電学論 B, 114, 10 pp.1050-1058 (1994-10)

14) “Transmission Line Reference Book", Electric Power Research Institute, $345 \mathrm{kV}$ and Above/Second Edition, pp.551-552 (1982)

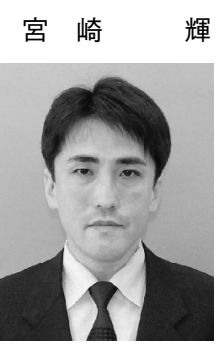

輝（正員） 1997 年 3 月電気通信大学大学院情報シ ステム学研究科修士課程修了。同年 4 月東京電力 (株) 入社。現在，技術開発研究所高電圧・絶縁技 術グループ所属。主として，配電系統の雷観測・ サージ解析に関する研究に従事。

岡 部成 光

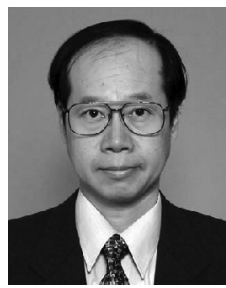

饗 場潔

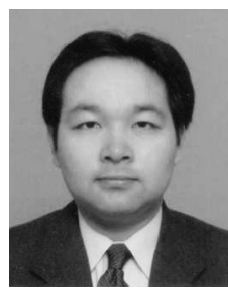

平井崇夫

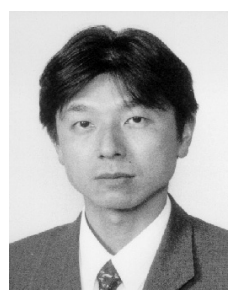

吉 永

淳

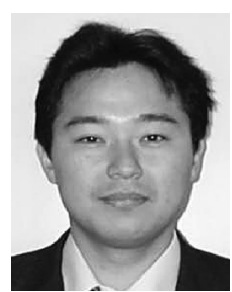

（上級会員） 1986 年 3 月東京大学大学院工学研 究科電気工学専攻博士課程修了。同年 4 月東京電 力 (株) 入社。1 1992 年ミュンヘン工科大学客員研 究員。現在, 技術開発研究所高電圧・絶縁技術グ ループマネージャー。工学博士。IEEE 会員。

(正員) 1993 年 3 月慶應義塾大学大学院理工学 研究科計測工学専攻修士課程修了。同年 4 月東京 電力 (株) 入社。現在, 技術開発研究所高電圧. 絶縁技術グループ所属。主として, 配電系統の雷 観測・サージ解析に関する研究に従事。

（正員） 1991 年 3 月早稲田大学理工学部電子通 信学科卒業。同年 4 月東京電力 (株) 入社。現在, 配電部配電技術グループに勤務。技術開発研究所 在籍時に配電線雷観測研究に従事。

（正員） 1994 年 3 月大阪大学大学院工学研究科 生産加工工学専攻博士課程前期修了。同年 4 月東 京電力（株）入社。現在, 配電部配電技術グルー プに勤務。技術開発研究所在籍時に配電系統, 配 電機材に関する研究に従事。 